\title{
Implementasi Cyber Counseling Dalam Meningkatkan Social Intelligence Mahasiswa Introvert Di Universitas Pgri Banyuwangi
}

\author{
Siti Napisah ${ }^{1}$, Raup Padillah ${ }^{2}$. \\ ${ }^{1}$ Psikologi, Universitas PGRI Banyuwangi \\ 2 Teknologi Pembelajaran, Universitas PGRI Banyuwangi \\ Email: napisah.s71@gmail.com, raup.padillah@gmail.com
}

\begin{abstract}
Social intelligence is one's ability make sensitive to other people's feelings. Interactions between people who are not based on good social intelligence will lead to various conflicts. This situation will become an obstacle for develop quality of each student involved. Based on observations and observations made by researchers while giving courses at PGRI Banyuwangi University, in almost every class there are students who included in the introvert category. One effort can be done to help students like this is to do cyber counseling. This study aims to measure extent of implementation of cyber counseling in improving social intelligence of introverted students at PGRI Banyuwangi University. This research is an action research counseling (action research in counseling) study that designed in two cycles and each cycle performed 4 times. The overall implementation of cyber counseling with 8 times, 4 times on the elbow 1 and 4 times in cycle 2 . Stages of implementation in this study include: (a) Planning, (b) Implementation, (c) Observation, and (d) Reflection. Overall results from cycle 1 and cycle 2, there was an increase in each social intelligence indicator that observed in 20 introverted students at the PGRI Banyuwangi University. The highest increase was in the aspects of Clarity, and Empathy, each at 50\%. Based on the results of research that researchers have done, cyber counseling can used to help introverted students who tend to experience social problems. This shown in the results of observations and measurements in the process of cycle 1 and cycle 2 .
\end{abstract}

Keywords : Cyber Counseling; Social Intelligence; Introvert.

\section{PENDAHULUAN}

Kecenderungan mahasiswa yang berkepribadian introvert adalah rendahnya kemampuan komunikasi, sering gagal dalam berinteraksi, dan kurang mahir dalam bersosialisasi. Hal ini tentu saja mempengaruhi perkembangan akademis mahasiswa karena salah satu aspek dalam dunia akademis yang dinilai adalah aspek afektifnya.

Kepribadian introvert merupakan kepribadian yang tertutup, sehingga cenderung memilih sendiri atau bertemu dengan sedikit teman. Seseorang yang berkepribadian introvert mengarahkannya ke dunia dalam diri sendiri, para introvert lebih berpikir ke arah subjektif dirinya sendiri (Nursyahrurahmah, 2007) . Kepribadian introvert kesulitan mengembangkan hubungan sosial dan lebih memilih berkomunikasi secara pribadi dengan teman serta menikmati setiap kegiatan yang dapat dilakukan sendirian atau bersama teman dekat (Erica, et al. 2015).

Mahasiswa yang memiliki kepribadian introvert sering mengalami kesulitan ketika dihadapkan pada situasi yang mengharuskan mereka melakukan interaksi sosial. Hal ini berdampak pada peranan mereka terhadap beberapa aktifitas perkuliahan khususnya pada tugas-tugas kelompok yang dituntutut kerjasama dalam pengerjaannya. Mahasiswa yang memiliki kepribadiaan introvert merupakan individu yang memiliki kekurangan dalam 
hubunngan sosial baik secara kualitas maupun kuantitas. Hal ini berdampak pada sikap cenderung menyerah pada keadaan serta tertinggal dalam mengikuti perkembangan keadaan (Ghufron., Riswanita, 2010).

Social intelligence (kecerdasan sosial) merupakan kemampuan seseorang untuk peka terhadap perasaan orang lain. Mereka cenderung untuk memahami dan berinteraksi dengan orang lain sehingga mudah bersosialisasi dengan lingkungan di sekelilingnya (Nasehudin, 2015). Kecerdasan sosial perlu dikembangkan agar individu dapat membina interaksi sosial dalam keberagaman (Soejanto, LT., Soekarman, F.I. 2015). Interaksi antar individu yang tidak dilandasi oleh kecerdasan sosial yang baik akan menimbulkan berbagai konflik. Keadaan seperti ini akan menjadi penghalang bagi berkembangnya kualitas diri setiap mahasiswa yang terkait.

Berdasarkan observasi dan hasil pengamatan yang dilakukan oleh peneliti selama memberikan mata kuliah di Universitas PGRI Banyuwangi, hampir disetiap kelas terdapat mahasiswa yang masuk dalam kategori introvert. Mahasiswa seperti ini cenderung mengalami kesulitan ketika mengerjakan tugas kelompok dan kegiatan-kegiatan yang berkaitan dengan interaksi sosial. Hal ini berdampak pada terhambatnya perkembangan dan prestasi akademik akibat ketidak mampuan bekerja sama dan menjalin komunikasi yang baik. Mahasiswa seperti ini cenderung suka menyendiri dan selalu pulang lebih awal dari mahasiswa yang lain. Karakter menutup diri ini menyulitkan dosen dalam mengembangkan potensi dan prestasi akademiknya. Salah satu upaya yang dapat dilakukan untuk membantu mahasiswa seperti ini adalah dengan melakukan cyber counseling.

Cyber counseling merupakan sebuah praktik konseling profesional dan merupakan sebuah proses pengiriman pesan yang terjadi ketika konseli dan konselor berada pada tempat yang terpisah atau dengan jarak yang berjauhan dan menggunakan media elektronik untuk berkomunikasi (Gibson, R. L. \& Mitchell, M. H. 2008., 2011). Konseling dengan model ini diharapkan dapat membantu permasalahan mahasiswa introvert dalam memperbaiki kecerdasan sosial (social intelligence) (Mulyatiningsih, Rudi. 2015., Albrecht, Karl. 2006).

Berdasarkan uraian latar belakang tersebut, penelitian ini bertujuan untuk mengukur sejauh mana implementasi cybercounseling dalam meningkatkan social intelligence mahasiswa introvert di Universitas PGRI Banyuwangi. Hasil penelitian ini diharapkan dapat membantu permasalahan yang dialami mahasiswa introvert di Universitas PGRI yang selama ini kesulitan dalam interaksi sosial dan berdampak pada prestasi akademiknya.

\section{METODE PENELITIAN}

Penelitian tindakan bimbingan konseling ini dirancang dalam dua siklus dan masing-masing siklus dilakukan tindakan sebanyak 4 kali. Tindakan dilakukan sekali dalam satu minggu. Implementasi cybercounseling secara keseluruhan dilakukan sebanyak 8 kali, 4 kali pada siklus 1 dan 4 kali pada siklus 2. Tahapan pelaksanaan pada penelitian ini antara lain: (a) Perencanaan, (b) Pelaksanaan, (c) Pengamatan, dan (d) Refleksi. Prosedur penelitian lebih jelasnya dapat dilihat pada gambar berikut (Hasan, 2004) : 


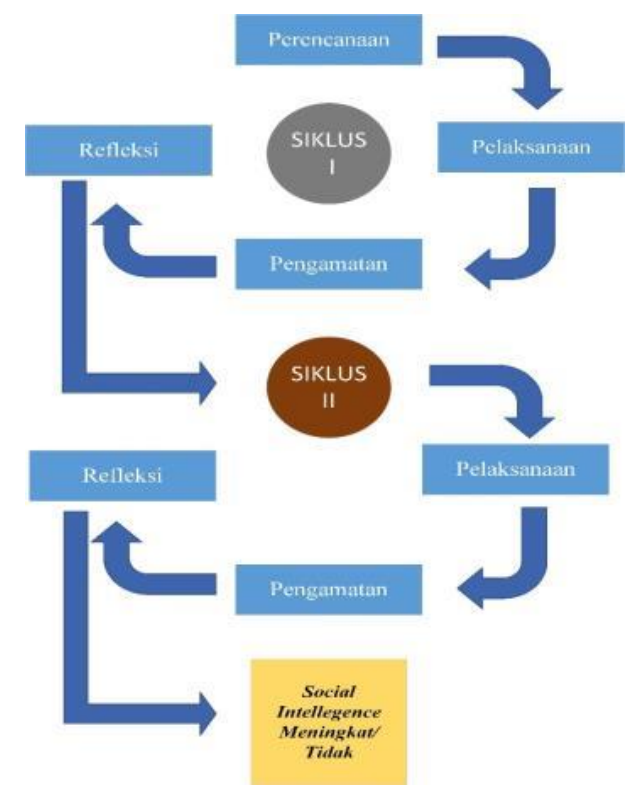

Gambar 1. Diagram Alir Penelitian

a) Tahap Perencanaan Pada tahap ini, peneliti identifikasi masalah, analisis dan perumusan masalah, dan penetapan rencana tindakan. b) Tahap Pelaksanaan Pada tahap ini, peneliti melakukan persiapan pelaksanaan tindakan implementasi cybercounseling. Persiapan yang dilakukan peneliti antara lain : rencana dan skenario, fasilitas /sarana pendukung, cara merekam/ mencatat dan mengana-lisis data proses perbaikan. c) Tahap Pengamatan Pada tahap ini, peneliti melakukan observasi pada tindakan yang dilakukan. Observasi, Evaluasi dan Interpretasi dilaksanakan bersamaan dengan pelaksanaan tindakan. d) Refleksi Reflleksi diawali dengan kegiatan analisis data, yaitu menyeleksi dan mengelompokkan data, memaparkan dan mendeskripsikan data dalam bentuk narasi, tabel, dan/atau grafik, serta menyimpulkan secara deklaratif. Hasil pengumpulan data dianalisis, dicek ulang, dan hasil refleksi tersebut digunakan untuk perencanaan tindakan di siklus selanjutnya.

\section{HASIL DAN PEMBAHASAN}

Indikator yang diamati pada penelitian ini adalah kecerdasan sosial (Social Intelligence) yang dapat dilihat pada tabel berikut:

Tabel 1. Indikator Social Intelligence

\begin{tabular}{|c|l|l|}
\hline No. & \multicolumn{1}{|c|}{ Indikator } & \multicolumn{1}{|c|}{ Perilaku yang Diamati } \\
\hline 1 & Situational awareness & $\begin{array}{l}\text { Memahami dan peka akan kebutuhan serta hak } \\
\text { orang lain. }\end{array}$ \\
\hline 2 & Presense & $\begin{array}{l}\text { Etika penampilan, tutur kata dan sapa yang } \\
\text { diungkapkan gerak tubuh ketika bicara dan } \\
\text { mendengarkan. }\end{array}$ \\
\hline 3 & Authenticity & $\begin{array}{l}\text { Sinyal dari perilaku yang membuat orang lain } \\
\text { menilai sebagai orang yang layak dipercaya } \\
\text { (trusted), jujur, dan terbuka. }\end{array}$ \\
\hline 5 & Clarity & $\begin{array}{l}\text { Kemampuan menyampaikan gagasan dan ide } \\
\text { secara mudahdan persuasif sehingga orang lain } \\
\text { bisa menerimanya dengan tangan terbuka. }\end{array}$ \\
\hline
\end{tabular}

\section{Kegiatan Siklus 1}

Berdasarkan hasil observasi yang dilakukan oleh peneliti, masih terdapat mahasiswa yang mengalami kesulitan dalam berkomunikasi verbal. Selain itu, masih terdapat mahasiswa yang 
masih kesulitan dalam memahami maksud pemikiran orang lain. Berikut adalah tabel analisis hasil observasi terhadap 20 mahasiswa introvert yang ada di Universitas PGRI Banyuwangi:

Tabel 2. Keterampilan Social Intelligence pada mahasiswa Introvert di Universitas PGRI Banywuangi

\begin{tabular}{|c|c|c|}
\hline Kategori & Jumlah & Prosentase (\%) \\
\hline Tinggi & 4 & 20 \\
\hline Sedang & 7 & 35 \\
\hline Rendah & 9 & 45 \\
\hline
\end{tabular}

Pada saat dilaksanakannya siklus 1 terdapat beberapa kendala pada saat pelaksanaan cyber counseling. Permasalahan tersebut disebabkan antara lain:

1. Mahasiswa belum mengerti dampak dari rendahnya keterampilan berbicara terhadap perkembangan karirnya, sehingga selama kegiatan konseling kurang partisipatif.

2. Terdapat beberapa mahasiswa yang beranggapan berkomunikasi dengan seseorang yang tidak dikehendaki merupakan pilihan terbaik dalam interaksi dan komunikasi sosial.

3. Akses internet pada responden terkadang mengalami gangguan.

Tes akhir pada siklus 1 dilakukan dengan tujuan mengukur sejauh mana indikatorindikator kecerdasan sosial muncul pada responden yang sudah ditentukan. Hasil pengukuran pada siklus 1 dapat dilihat pada tabel berikut:

Tabel 3. Hasil Pengamatan Siklus 1

\begin{tabular}{|l|c|c|}
\hline \multicolumn{1}{|c|}{ Indikator yang diamati } & Responden (20) & Prosentase (\%) \\
\hline Situational awareness & 15 & 75 \\
\hline Presense & 13 & 65 \\
\hline Authenticity & 15 & 75 \\
\hline Clarity & 7 & 35 \\
\hline Empathy & 8 & 40 \\
\hline
\end{tabular}

Setelah dilakukan serangkaian kegiatan cyber counseling pada 20 responden mahasiswa introvert, terdapat dua indikator yang hasilnya rendah, yaitu pada aspek Clarity, dan Empathy. Dengan hasil pengamatan pada siklus 1 tersebut, peneliti melanjutkan pada tahap pelaksanaan siklus 2 untuk mengetahui perubahan hasil pada siklus 1 .

\section{Kegiatan Siklus 2}

Pada saat pelaksanaan siklus 2, beberapa permasalahan yang terjadi padaa saat siklus 1 berhasil diatasi dengan baik. Hal ini berdasarkan hasil observasi peneliti antara lain:

1. Setelah mahasiswa mengerti dampak positif dari keterampilan berbicara, mahasiswa lebih aktif dan partisipatif dalam melaksanakan cyber counseling yang dilakukan.

2. Mahasiswa dapat melakukan komunikasi dengan baik meskipun dengan lawan bicara yang tidak dia kehendaki.

3. Gangguan pada masalah akses internet diatasi dengan melakukan cek dan kontrol terhadap kualitas koneksi pada responden.

Tes akhir pada siklus 2 dilakukan dengan tujuan mengukur perbedaan hasil yang didapat setelah dilaksanakannya siklus 1 . Hasil pengukuran pada siklus 2 dapat dilihat pada tabel berikut: 
Tabel 4. Hasil Pengamatan Siklus 2

\begin{tabular}{|l|c|c|}
\hline \multicolumn{1}{|c|}{ Indikator yang diamati } & Responden (20) & Prosentase (\%) \\
\hline Situational awareness & 18 & 90 \\
\hline Presense & 17 & 85 \\
\hline Authenticity & 18 & 90 \\
\hline Clarity & 17 & 85 \\
\hline Empathy & 18 & 90 \\
\hline
\end{tabular}

Rendahnya aspek Clarity, dan Empathy pada hasil siklus 1 meningkat pada saat hasil pengukuran siklus 2. Hasil pengamatan pada siklus 2 menunjukan adanya perubahan perilkau pada 20 responden yang diamati setelah dilakukan cyber counseling.

\section{Refleksi}

Refleksi dilakukan oleh peneliti bersama dengan konselor yang ada pada tim setelah serangkaian proses pada siklus 2 berakhir. Dari hasil refleksi pada siklus 1 dan 2, terbukti proses pelaksanaan cyber counseling pada siklus 2 lebih baik dengan dibuktikan peningkatan munculnya indikator pada responden yang diobservasi. Pada hasil pengukuran di siklus 2, aspek Clarity, dan Empathy yang awalnya rendah pada siklus 1 mengalami peningkatan pada hasil akhir di siklus 2 .

\section{Pembahasan}

Setelah serangkaian kegiatan cyber counseling yang sudah dilaksanakan baik pada siklus 1 maupun siklus2, berikut hasil pengukuran kegiatan konseling secara keseluruhan:

Tabel 5. Perbandingan Hasil Pengamatan Siklus 1 dan Siklus 2

\begin{tabular}{|l|c|c|}
\hline \multicolumn{1}{|c|}{ Indikator yang diamati } & Siklus 1 (\%) & Siklus 2 (\%) \\
\hline Situational awareness & 75 & 90 \\
\hline Presense & 65 & 85 \\
\hline Authenticity & 75 & 90 \\
\hline Clarity & 35 & 85 \\
\hline Empathy & 40 & 90 \\
\hline
\end{tabular}

Hasil secara keseluruhan dari siklus 1 dan siklus 2, terdapat peningkatan pada setiap indikator kecerdasan sosial yang telah diamati pada 20 mahasiswa introvert yang ada di Universitas PGRI Banyuwangi. Peningkatan yang paling tinggi adalah pada aspek Clarity, dan Empathy yaitu masing-masing sebesar 50\%.

\section{KESIMPULAN}

Kecenderungan mahasiswa yang berkepribadian introvert adalah rendahnya kemampuan komunikasi, sering gagal dalam berinteraksi, dan kurang mahir dalam bersosialisasi. Hal ini tentu saja mempengaruhi perkembangan akademis mahasiswa karena salah satu aspek dalam dunia akademis yang dinilai adalah aspek afektifnya. Pelaksanaan cyber counseling bertujuan untuk meningkatkan kecerdasan sosial (Social Iintelligence) pada mahasiswa introvert. Berdasarkan hasil penelitian yang sudah peneliti lakukan, cyber counseling dapat digunakan untuk membantu mahasiswa introvert yang cenderung mengalami permasalahan sosial. Hal tersebut dibuktikan pada hasil pengamatan dan pengukuran pada proses siklus 1 dan siklus 2 . 


\section{DAFTAR PUSTAKA}

Albrecht, Karl. (2006). Social Intelligence: the new science of success. en.bookfi.org. Diakses pada tanggal 8 Agustus 2018.

Erica McIntyre, Karl K.K. Wiener, Anthony J. Saliba. (2015). Compulsive Internet Use and Relations Between Social Connectedness, and Introversion. Journal Computers in Human Behavior 48: 569-574.

Ghufron., Riswanita. (2010). Teori-Teori Psikologi. Yogyakarta: ArRuzz Media.

Gibson, R.L. \& Mitchell M.H. 2008. Introduction to counseling and Guidance. New York: Macmillan Publisher.

Gibson, R. L. \& Mitchell, M. H. (2011). Bimbingan dan konseling. Diterjemahkan oleh Yudi Santoso. Yogyakarta: PustakaPelajar.

Hasan, I. (2004). Analisis Data Penelitian Dengan Statistik. Jakarta: PT. Bumi Aksara.

Mulyatiningsih, Rudi. (2015). Konseling melalui Dunia Maya (Cyber Counseling)" dalam Kompasiana. Jakarta: 24 Juni. Tersedia secara online di: https://www.kompasiana. com/rudimulyatiningsih/konseling-melaluidunia-maya [diakses di Banyuwangi, Jawa Timur, Indonesia: 8 Agustus 2020).

Nasehudin. (2015). Mengembangkan Kecerdasan Sosial Dalam Proses Pendidikan. Edueksos: Jurnal Pendidikan Sosial \& Ekonomi. 4(2).

Nursyahrurahmah. (2007). Hubungan Antara Kepribadian Introvert Dan Kelekatan Teman Sebaya Dengan Kesepian Remaja. Jurnal Ecopsy. 4 (2): 113-116.

Soejanto, LT., Soekarman, F.I. (2015). Tingkat Kecerdasan Sosial Mahasiswa Fakultas Keguruan dan Ilmu Pendidikan Universitas Kanjuruhan Malang. Jurnal Konseling Indonesia. 1(1) : 14-22. ISSN 2475-8881. 